\title{
ガスエンジンシステムに対する発電機と貯湯槽の容量設計法
}

家庭用コージェネレーションシステムの計画・設計手法に関する研究 その 1

\section{DESIGN METHOD OF GENERATOR CAPACITY AND D.H.W TANK VOLUME FOR RESIDENTIAL GAS-ENGINE CO-GENERATION SYSTEM}

Planning and design method of co-generation system for residence Part 1

\author{
田中英 紀*1, 石橋 良太郎*2，足 立 拓 哉*3，奥 宮 正 哉*4 \\ Hideki TANAKA, Ryotaro ISHIBASHI, Takuya ADACHI \\ and Masaya OKUMIYA
}

This study aims to propose a planning and design method for a residential co-generation system. This paper discuss about a gas-engine generator system. The system simulation program is developed to analyze the system behavior and the performance, and the program is verified in comparison between simulation results and experimental data. It is represented that rated power generation with appropriate schedule is effective operation method for a gas-engine generator system and the system energy performance correlates closely with the ratio of heat load to electric power load. And then, the design method for the capacity of generator and D.H.W tank are proposed using by Rge that is the ratio of rated generator output to hourly peak demand in intermediate season and $R s t$ that is the ratio of the tank capacity to daily heat load in winter.

Keywords : Co-generation system, Residential system, Micro co-generation, Gas-engine generator コージェネレーションシステム, 家庭用システム, マイクロコージェネレーション, ガスエンジン発電機

\section{1. はじめに}

現在、家庭用コージェネレーションシステム(以下、家庭用 CGS と 記す)の開発が本格化しており、既にガス供給事業者や機器メーカ等 により $1 \mathrm{~kW}$ 程度の家庭用ガスエンジン $(\mathrm{GE})$ 発電機や固体高分子形 然料電池 $(\mathrm{PEFC})$ 等が開発されている。このうち GE システムは既 に実用化されており、PEFCについても数々の実証試験等注1)を経て、 まもなく本格的な市場導入を開始しつつある。しかしながら、この 分野における既往の研究は、実証的研究 ${ }^{1) 2}$ ) や要素技術開発 ${ }^{3)}$ 、特定 システムの性能試算 ${ }^{45}$ )5)等にとどまっておら、システム計画・設計 手法は未だ明らかにされていないため、その確立が望まれている。

そこで、本研究では家庭用 CGSに対する解析プログラムを開発し、 この解析結果をもとに家庭用 CGS の計画・設計手法を提案すること を目的とする。本論では、既に市場導入が開始されている GE 発電 機による家庭用 CGS を対象に取り上げ、まず実試験データをもとに 解析プログラムの妥当性を評価した。次に発電機の運転形態として 定格運転と電力負荷追従運転を想定し、エネルギー性能解析の結果 比較から有効な運転手法を示した。さらに、家族構成や住まい方な どを変化させた種々の住宅負荷を想定した解析結果をもとに、GE システムに対する導入効果の予測手法と、システムの主構成要素で ある発電機および貯湯槽に対する容量選定方法の提案を行った。

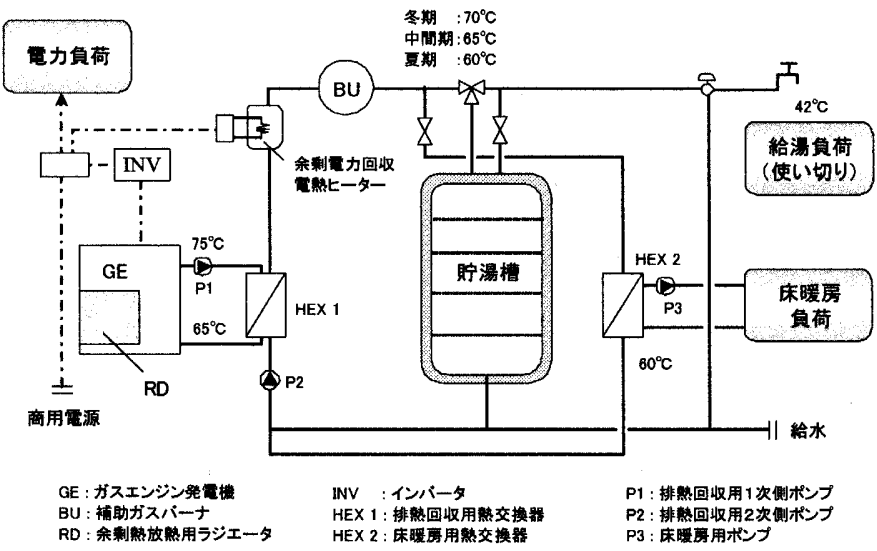

図 1 家庭用コージェネレーションシステム

\section{2. 対象システムの構成と基本運転パターン}

図 1 に検討対象システムの概要を示す。システムは、GE 発電機と インバータ、給湯用貯湯槽と補助ガスバーナ(効率 0.8 と仮定)、水 循環ポンプ (P1:39W，P2：60W，P3：100W）から構成される。 システムでは、建物の電力負荷を発電機による発電電力で賄い、 全電力負荷を発電電力のみで処理できない場合には、不足分を商用
*1 名古屋大学大学院工学研究科 助手 - 博士 (工学)

*2 侏) 竹中工務店 修士(環境学)

*3 鹿島建設(俳) 修士(環境学)

*4 名古屋大学大学院環境学研究科 教授・工博
Assistant Prof., Graduate School of Engineering, Nagoya Univ., Dr. Eng. Takenaka Corporation, M. Env.

Kajima Corporation, M. Env.

Prof., Graduate School of Environmental Studies, Nagoya Univ., Dr. Eng. 
系統から買電する。また、発電機を定格運転した場合など、住宅の 電力負荷より発電量が上回る時間帯については、余剩電力を電熱上 一タにて熱変換し、回収するものとした注2)。

発電機からの回収排熱は給湯および床䁔房負荷の加熱源として用 い、不足熱量分は補助ガスバーナにより補われ、回収排熱量に余剩 が生じた場合には、その余剩排熱を貯湯槽に貯える。給湯負荷に対 する処理熱源の優先順位は、発電機排熱の直接利用、貯湯槽から出 湯（各期の出湯温に至るまで）、補助ガスバーナの順としている。

発電機は、設定した運転スケジュール内において起動信号が継続 して出され、これに従い運転されるが、設定スケジュール内であっ ても貯湯槽が満蓄状態（槽下部温度 で停止する (運転再開の条件は、槽下部温度＝排熱回収温度 $-5^{\circ} \mathrm{C}$ )。

排熱回収ポンプ(図 $1:$ P2)は、貯湯槽側の排熱回収温度をもとに 変流量 (回転数)制御され、GE 冷却水ポンプ(図 1:P1) は定流量制御 をとる。また、排熱回収熱交換器の $\mathrm{GE}$ 側出口温度が $65^{\circ} \mathrm{C}$ 以上とな

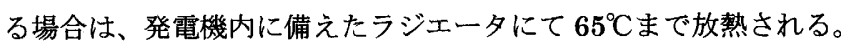

\section{3. シミュレーションプログラム}

\section{1 プログラム概要}

開発した家庭用 CGS の解析プログラムは、静的エネルギーシミュ レーションプログラムである。プログラムでは、与えられた住宅負 荷条件および制御条件をもとに、計算時刻毎の発電機出力、熱交換 器の交換熱量、各系統の流量や貯湯槽内の温度分布などを計算し、 その結果として得られる発電機、補助ガスバーナ、循環ポンプのエ ネルギー消費量ならびに買電量からシステム性能の算定を行う。

また、プログラムには、種々の発電機容量と貯湯槽容量さらには 発電機運転スケジュールを与えて総当たり計算を行い、検討範囲の 中から年間エネルギー性能が最も高くなる組み合わせを選択できる 容量適正化機能を持たせている注3)。

主要なサブシステムモデルは、発電機, 排熱回収用熱交換器, 貯 湯槽、ポンプなどである。適用した計算モデルを以下に概説する。

\section{2 サブシステムモデル}

(1) ガスエンジン発電機

$\mathrm{GE}$ 発電機の発電出力および排熱出力は、図 2 の特性曲線注4)をも

とに計算を行い、発電機容量を変更した場合もこの特性に準ずると した。発電機からの排熱出口水温は $75^{\circ} \mathrm{C}$ とし、貯湯槽側の排熱回収 温度は、冬期 $\left(12 \sim 3\right.$ 月) $: 70^{\circ} \mathrm{C}$, 中閒期 $\left(4 \sim 6\right.$ 月, $10 \sim 11$ 月) $: 65^{\circ} \mathrm{C}$,

夏期 (7〜9月)：60泉季節毎に設定を変更する。

(2) 貯湯槽

温度成層を形成する貯湯槽内の温度分布は、繸方向 5 層に仮想分 割して計算を行っている。槽内は完全な押し出し流れを形成すると し、貯湯時の下部取り出し・上部入力、出湯時の上部取り出し・下部 入力など、時々刻々のシステム挙動に忘じて移流が与えられる。

賍湯槽の断熱性能は $0.87 \mathrm{~W} /\left(\mathrm{m}^{2} \cdot \mathrm{K}\right)$ であり、仮想分割槽毎の槽内水 温とタンク迴りの年平均温 $16^{\circ} \mathrm{C} の$ 温度差に表面積を乗じて熱損失 量を算出している。

\section{（3）熱交換器}

排熱回収または床暖房用の熱交換器には、対向流型の水-水熱交換

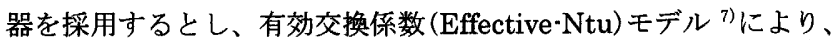
二流体の熱交換器出口温度が計算される。

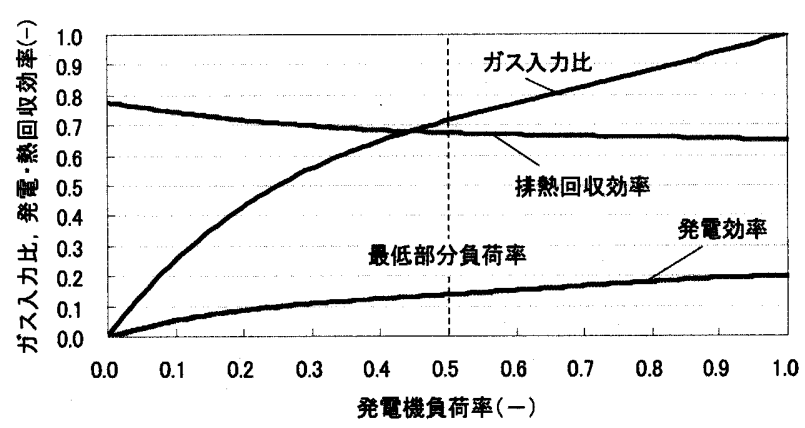

図 $2 \mathrm{GE}$ 発電機の部分負荷特性

表 1 実験装置の仕様と実験条件

\begin{tabular}{|c|}
\hline 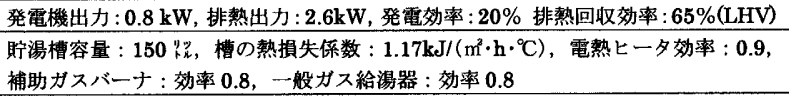 \\
\hline $\begin{array}{l}\mathrm{GE} \text { 排熟温度 : } 75^{\circ} \mathrm{C} \text {, 排熱回収温度 : } 60^{\circ} \mathrm{C} \text {, 給水温度 : } 14.8^{\circ} \mathrm{C} \text {, 給湯温度 : } 42^{\circ} \mathrm{C} \text {, } \\
\text { 貯湯槽最下層 } 55^{\circ} \mathrm{C} \text { 以上で満蓄判定 }\end{array}$ \\
\hline 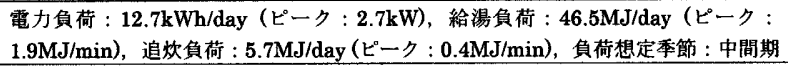 \\
\hline GE 運転スケジュール設定： $16: 37 \sim 18: 19,20: 38 \sim 23: 50$ \\
\hline
\end{tabular}

(4) 循環ポンプ

排熱回収ポンプ（図 1:P2）は回転数制御特性 ${ }^{8}$ )による変流量制 御、発電機ジャケット水用および床暖房用の循環ポンプ（図 1:P1 およびP3）は定流量制御されるとして、ポンプ動力が算定される。

\section{3 システムの評洒指標}

全体システムの評価は、基準システムに対する一次エネルギー削 減率注 5)で評価した。なお、本論では電力需要は全て買電、給湯需要 はガス給湯器、床暖房を備える場合はガス式床暖房を用いて賄うも のを基準システムとして設定している。発電機まわりエネルギー評 価指標は SHASE-M ${ }^{9}$ に準じるが、排熱利用率 $R_{w h}$ 、CGS 依存率 $\sigma$ および CGS 総合効率 $C G S_{\text {eff }}$ は、式(1)〜(4)のように定義した。

$$
\begin{aligned}
R_{w h} & =\left(Q_{w h}+Q_{e h}-Q_{r d}-Q_{l o s s}\right) /\left(Q_{w h}+Q_{e h}\right) \\
\sigma_{e} & =\left(E_{l d}-E_{u t}\right) / E_{l d} \\
\sigma_{h} & =\left(Q_{l d-d}+Q_{l d-f}-Q_{b u}\right) /\left(Q_{l d-d}+Q_{l d-f}\right) \\
C G S_{e f f} & =\left\{3.6 \cdot\left(E_{g e}-E_{p e x}-E_{e h}\right)+Q_{w h}+Q_{e h}-Q_{l o s s}-Q_{r d}\right\} / 46.05 \cdot G_{g e}
\end{aligned}
$$

\section{4 プログラムの妥当性}

開発プログラムの解析結果を実試験データ注6) と比較して、その妥 当性を評価した。実験装膡の構成と基本的な制御方法は 2. で述べた 内容と同じであるが、実験は日中 $(10 〜 16$ 時の間)に貯湯槽が出湯で きる状態であっても出湯しない設定で行われている。解析は、計算 時間間隔を 1 分とし、表 1 と図 3 に示した実験装置の仕様と模擬負 荷条件の下で、システム条件を可能な限り摺り合わせて行った。

解析結果と実験データの比較結果を表 2 および図 4 図 8 に示す。 図より、発電機の稼働時間と熱回収のタイミングおよび回収熱量、 循環水温度や貯湯槽温度分布などの解析結果は、実システムの挙動 状況に対して良い一致を示している。また、表 2 より解析では配管 系熱損失を考虑していないために熱損失をやや少なく見積もる傾向 はあるが、実験と解析でシステム各要素の入出熱量等に大きな差は 見られず、模擬住宅負荷における日積算一次エネルギー消費量の誤 差についても約 $3 \%$ と僅かとなった。これらの結果から、解析プログ ラムによる計算結果は、実システム対して妥当であると判断した。 
表 2 各システム要素の入出熱量等の比較

\begin{tabular}{|c|c|c|}
\hline 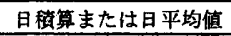 & 奏测 & 解析 \\
\hline 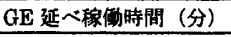 & 294 & 294 \\
\hline GEガス消費量 $\left(\mathbf{m}^{3}\right)$ & 1.69 & 1.67 \\
\hline GE 発電量 $(\mathrm{kWh})$ & 3.9 & 3.85 \\
\hline GE 排熱量 (MJ) & 45.9 & 45.1 \\
\hline 余剩発電電力量 (kWh) & 1.0 & 0.68 \\
\hline HEX1 交喚热量（MJ） & 43.0 & 45.1 \\
\hline 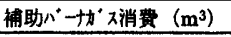 & 0.3 & 0.24 \\
\hline 配管·棈䳛損失 (MJ) & 4.1 & 1.7 \\
\hline 1 次现杫－消費量 (MJ) & 188.0 & 181.6 \\
\hline
\end{tabular}

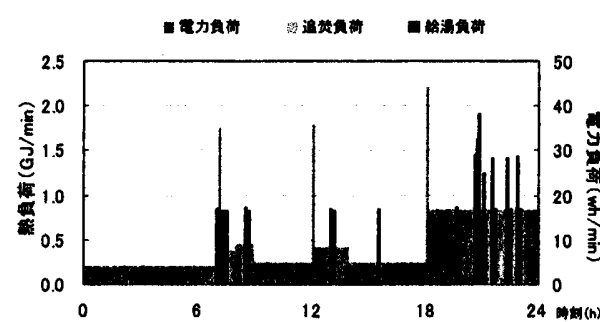

図 3 住宅負荷の条件

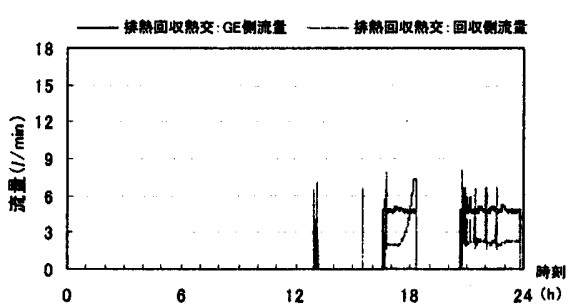

図 6 (a) 循環流量（実測値）

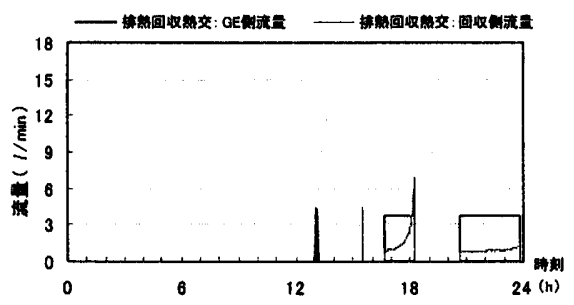

図 6 (b) 循環流量（計算值）

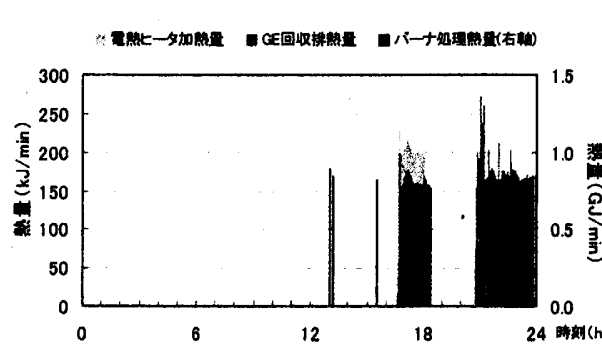

図 4 (a) 各種熱出力（実測值）

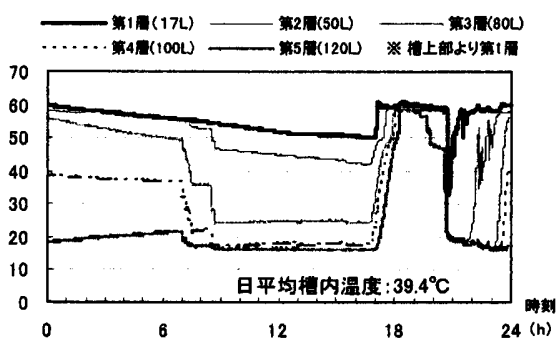

図 5 (a) 眝湯槽温度（実測值）

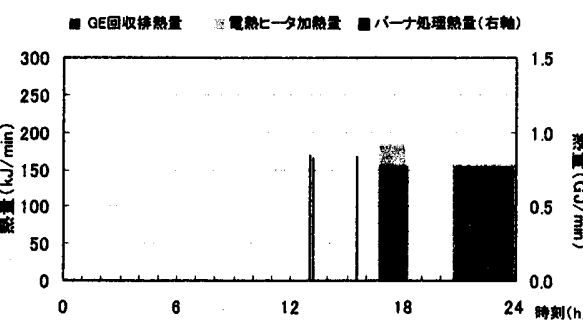

図 4（b）各種熱出力（計算値）

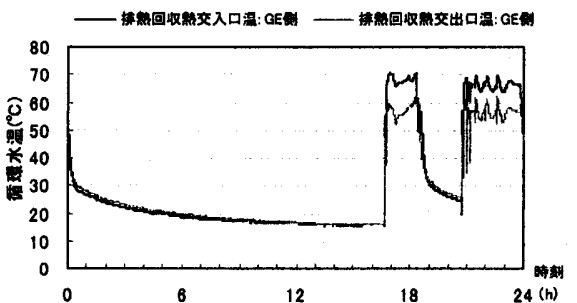

図 7 (a) 熱交換器出入口温：GE 側（実測値）

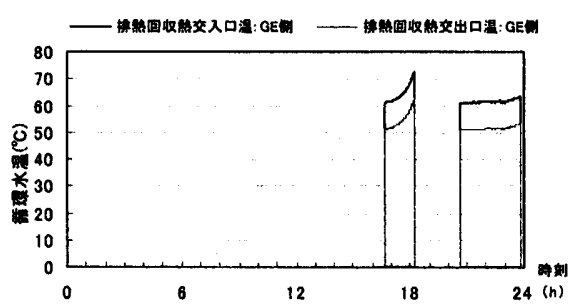

図 7 (b) 熱交換器出入口温：GE 側（計算値）

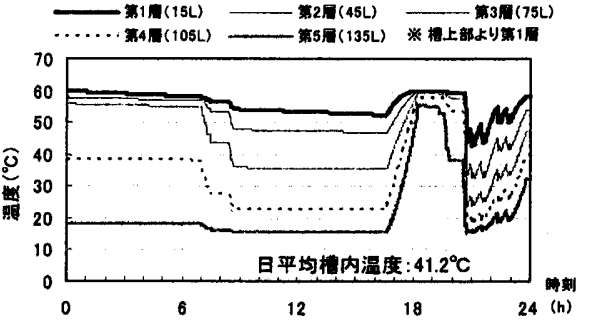

図 5 (b) 貯湯槽温度（計算値）

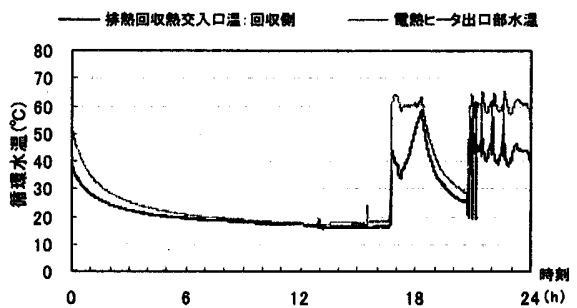

図 8 (a) 熱交換器出入口温 : 回収側（実測値）

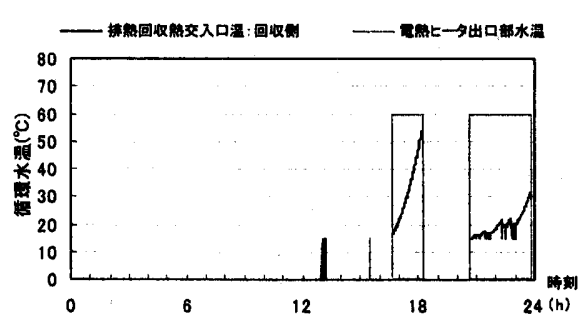

図 8 (b) 熱交換器出入口温 : 回収側（計算値）

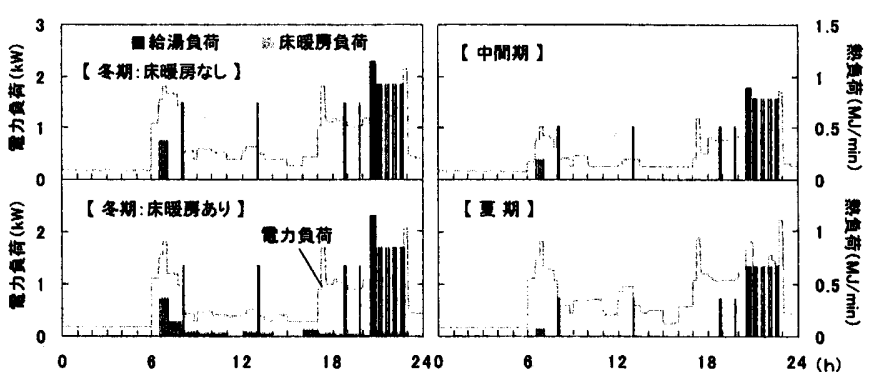

図 9 (a) 核家族住宅(住宅 4) の平日負荷パターン

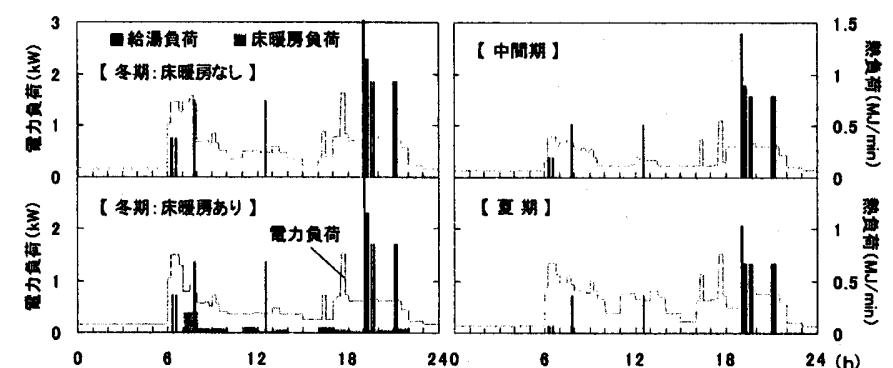

図 9 (b) 老夫婦住宅の平日負荷パターン

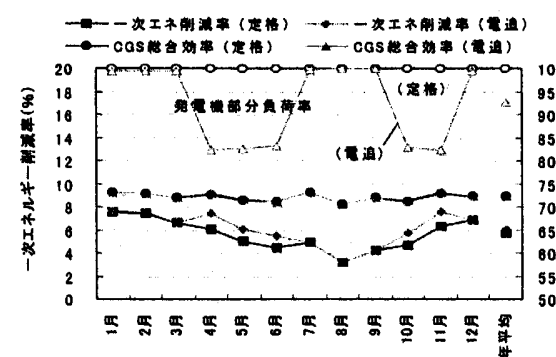

（a）省工ネ率，総合効率と発電機部分負荷率

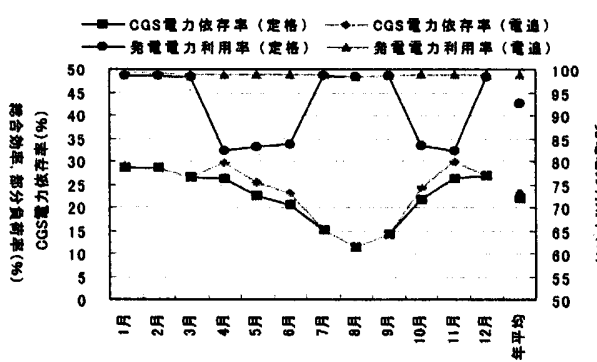

（b）CGS 電力依存率と発電電力利用率

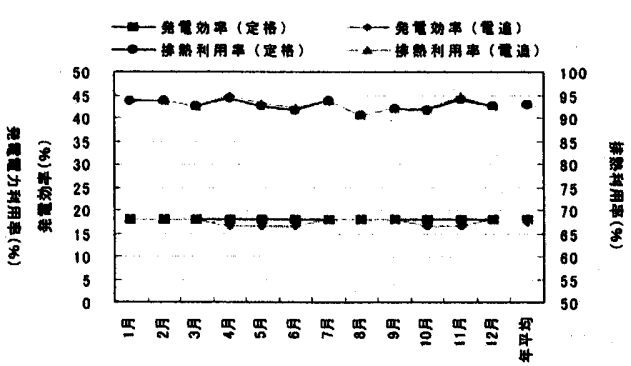

（c）発電効率と排熱利用率

図 10 定格運転と電力負荷追従運転のシステム性能比較 
表 3 給湯使用量の設定条件

\begin{tabular}{|c|c|c|c|c|}
\hline \multirow{2}{*}{ 行 為 } & \multicolumn{3}{|c|}{ 核家族 } & \multirow[b]{2}{*}{ 老夫婷 } \\
\hline & 少消婁型 & 操準型 & 多消费型 & \\
\hline 洗面·洗留 & 水て洗面 & 渾で洗面 & 滆で洗面·洗策 & 鹖で洗面 \\
\hline 满はり (4) & $120 l$ & $150 \ell$ & $180 \ell$ & $150 \ell$ \\
\hline 入浴時 & 筫準型の $1 / 2$ 倍 & Default & 筫準型の 2 㥉 & Default \\
\hline 炊 事 & \multicolumn{4}{|c|}{ Default } \\
\hline
\end{tabular}

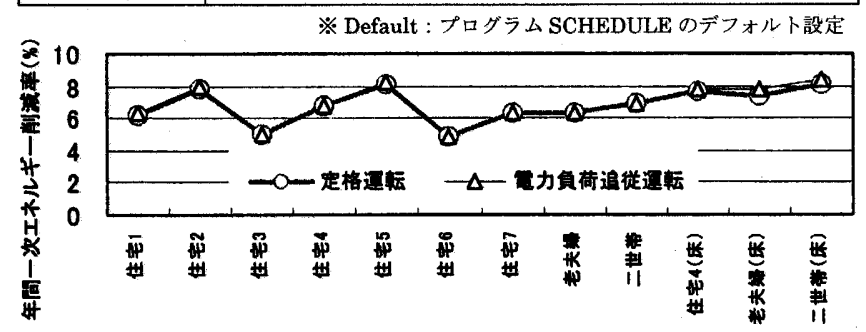

図 11 運転方法による年間エネルギー性能比較

\section{4. モデル住宅と住宅負荷}

\section{1 モデル住宅と対象家族}

本論では、東京に建ち次世代省エネ基淮を満たす延床面積約 $130 \mathrm{~m}^{2}$ の木造二階建てモデル住宅 ${ }^{10)}$ を前提に検討を行う。想定した 家族構成は、核家族 (夫婦と小·中学生)，老夫婦，二世帯（核家族 と老夫婦) の 3 条件とし、これらに対して床暖房を使用する場合 (床 暖房は居間のみに適用し、エアコン暖房との併用は考えない）と使用 しない場合を設定した。核家族で床暖房を使用しない条件ついては、 電力使用量と給湯使用量の各々について、(1)標準型，(2)少消費型，

(3)多消費型を想定し、計 12 の住宅負荷条件を設定した。

住宅の仕様は、家族構成にかかわらず同一のモデル住宅を用いる とし、老夫婦が住む場合には子供部屋の使用がないものとした。

\section{2 住宅負荷の算定方法}

一般電力負荷は、プログラム SCHEDULE ${ }^{11)}$ による解析結果に、 一般的に普及していると考えられる家電機器（電話機類やパソコン、 $\mathrm{AV}$ 機器など）や門灯などの外構照明を追加して作成した。核家族に 対しては、上記の手順にて作成した電力負荷を標準型とおき、これ を基準に建物内外の照明器具や家電機器を現実的なレベルで増減さ せることによって少消費型、多消費型の負荷を作成した。

空調熱負荷については、一般電力負荷算定時の結果をもとに各季 平·休日の室内発熱スケジュールを作成し、熱負荷計算プログラム $\mathrm{SMASH}^{12}$ を用いて在室空調時（夏期 $26^{\circ} \mathrm{C}$ ，冬期 $20^{\circ} \mathrm{C}$ ）の空調熱 負荷を求めた後、月平均日の負荷を作成した。核家族では、標準型 を在室空調、少消費型を朝晚のみ在室空調、多消費型を在室空調十 就寝時ベ一ス空調（就寝時：冷房 $28^{\circ} \mathrm{C}$, 暖房 $18^{\circ} \mathrm{C}$ ）として熱負荷 算定を行った。また、電気エアコン泠暖房を用いる場合は、最低消 費電力、外気温による能力補正や部分負荷特性を加味して消費電力 を求め、これと 0.5 回 $/ \mathrm{h}$ の計画換気（換気局方式）に対する消費電 力を一般電力負荷に加えて、各月の代表日に対する全電力負荷とし た。床暖房負荷については、対流暖房より $2^{\circ} \mathrm{C}$ 低い設定室温 $18^{\circ} \mathrm{C} の$ 在室空調を前提に SMASH による熱負荷計算を行って作成した。

給湯負荷は、SCHEDULE を用いて給湯使用量のパターンを作成 し、東京の給水温度 ${ }^{13)}$ と使用温度をもとに算定した。給湯用途は、 炊事，洗顔・洗髪，湯はり，入浴であり、表 3 の条件をもとに給湯 使用量のパターンを与えた。なお、二世帯住宅の住宅負荷は、核家 族と老夫婦の負荷を合成して作成を行った。図 9 には、核家族住宅 (住宅 4 ：後述) と老夫婦住宅の平日の負荷パターンを示す。

\section{5. 発電機の運転方法に関する検討 5. 1 発電機の運転条件}

CGS 発電機の運転手法としては、定格運転や電主熱従運転、熱主 電従運転などがある。2.で述べたように、システムはスケジュール 運転とともに貯湯槽の満蓄状態判定をもとに発電機の ON-OFF を 行うため、基本的には熱主電従運転である。本章ではこれを前提に、 電力負荷追従運転および定格運転を適用する場合のエネルギー性能 を解析し、この比較から有効な運転手段を判定する。

電力負荷追従運転では、発電機のエネルギー性能の低下を防ぐた めに最低部分負荷率を設定する必要がある。この値は予備検討を行 つて 50\%と定め注 7)、電力負荷が発電機の定格出力の $50 \%$ を下回る 時間帯には、最低部分負荷率 50\%を維持して発電するとした。

\section{2 解析結果と運転方法の選択}

先ずは、標準的な核家族 (住宅 4 : 表 4 の住宅条件表を参照) 住宅 に対し、現在市場投入されている発電容量 $1 \mathrm{~kW}$ (出力端, 発電効率 : $20 \%$ (LHV)，排熱回収効率 65\%(LHV)，排熱回収熱量 $11.7 \mathrm{MJ} / \mathrm{h}$ )、 貯湯槽容量 150 くの標準容量を導入する場合を想定して、発電機の運 転方法の違いによるエネルギ一性能を評価した。検討では、発電電 力に対する電力負荷への供給電力の割合を発電電力利用率として定 義し、これも評価指標として用いた。

図 10 に月別および年間システム性能の結果を示す。年間一次エネ ルギー削減率は、図 10 (a)に示すように発電機の運転方法に依らず 6\%程度となった。月別の削减率では、熱負荷の大きい冬期に最も向 上して約 $8 \%$ となるが、熱負荷の減少に伴って削減率も低下し、夏期 に最低の $3 \%$ 余りとなる。エアコン冷暖房により電力消費量が多くな る冬期および夏期には、電力負荷追従運転を採用しても期間平均の 発電機部分負荷率がほぼ $100 \%$ となり、定格運転と同等の運転状態 となる。しかし、中間期には電力負荷追従運転を行う時間数が增加 するため、発電機部分負荷率は低下する。この条件では、中間期の 平均発電機部分負荷率は、約 $83 \%$ となっている。

一方、定格運転では中間期に余剩電力が生じ、図 10 (b)に示すよ うに発電電力利用率が低下する。余剩電力を熱変換する際にはエネ ルギ一損失を伴い、加えて貯湯槽への回収排熱量が負荷追従運転を 行う場合に比べて増加するため、中間期には貯湯槽の水温が高く維 持されて、この期閒の槽熱損失が定格運転で $0.40 \mathrm{MJ}$ 、電力負荷追 従運転で $0.37 \mathrm{MJ}$ となり、定格運転で $8 \%$ 増加する。この結果として、 定格運転における中間期の排熱利用率は、電力負荷追従運転に比べ て約 3\%低下することとなった（図 10(c)）。

このように、発電機の運転方法として電力負荷追従運転を行うと、 定格運転に比べ中間期のエネルギー性能に若干の改善が見られるが、 年間性能で評価する場合にはその差は極めて僅かである。よって、 発電機の運転スケジュールが適正に設定されていれば注8)、二つの運 転手法のエネルギー性能は、ほぼ同程度になると考えられる。

上記結果の検証のため、4. で示した計 12 の住宅負荷条件に対し、 電力負荷追従運転および定格運転を適用した場合の解析も行った。 本検討では、各住宅負荷に対して 3.1 で述べた容量適正化を行い、 機器容量を与えている。図 11 に示すように、各住宅における年間エ ネルギー性能には、やはり両運転方法間で大きな差は見られない。

これらの結果を踏まえ、かつ現実性を考えると、単純な ON-OFF 制御となる定格運転の方が採用メリットは高いと結論付けられる。 
表 4 住宅負荷・年間熱電比とシステム装置容量

\begin{tabular}{|c|c|c|c|c|c|c|c|c|c|c|c|c|}
\hline \multirow{2}{*}{$\begin{array}{l}\text { 床暖房 } \\
\text { O有無 }\end{array}$} & \multirow{2}{*}{$\begin{array}{l}\text { 家族 } \\
\text { 種別 } \\
\end{array}$} & \multirow{2}{*}{ 凡例名 } & \multirow{2}{*}{ 電力消費 } & \multirow{2}{*}{ 給湯消費 } & \multicolumn{3}{|c|}{ 年䦥電力負荷（MWh） } & \multicolumn{2}{|c|}{ 年問熱負荷 (GJ) } & \multirow{2}{*}{$\begin{array}{c}\text { 熱電比* } \\
\text { (年間) }\end{array}$} & \multirow{2}{*}{$\begin{array}{c}\text { 発電機容量 } \\
(\mathbf{k W})\end{array}$} & \multirow{2}{*}{$\begin{array}{c}\text { 貯湯槽容 } \\
\text { (1) }\end{array}$} \\
\hline & & & & & 全電力 & 一般·照明 & エアコン & 給湯 & 床䁔房 & & & \\
\hline \multirow{9}{*}{ なし } & \multirow{7}{*}{ 核家族 } & 住宅 1 & 少 & 少 & 3.7 & 2.6 & 1.0 & 9.4 & - & 0.71 & 0.5 & 80 \\
\hline & & 住宅 2 & 少 & 標準 & 3.7 & 2.6 & 1.0 & 13.7 & - & 1.03 & 0.6 & 110 \\
\hline & & 住宅3 & 標隻 & 少 & 5.2 & 3.9 & 1.3 & 9.4 & - & 0.5 & 0.6 & 80 \\
\hline & & 住宅 4 & 標準 & 標倠 & 5.2 & 3.9 & 1.3 & 13.7 & - & 0.73 & 0.7 & 110 \\
\hline & & 住宅 5 & 標準 & 多 & 5.2 & 3.9 & 1.3 & 18.8 & - & 1.01 & 0.8 & 150 \\
\hline & & 住宅 6 & 多 & 標準 & 8.0 & 6.5 & 1.4 & 13.7 & - & 0.48 & 1.0 & 110 \\
\hline & & 住宅 7 & 多 & 多 & 8.0 & 6.5 & 1.4 & 18.8 & - & 0.66 & 1.2 & 180 \\
\hline & 老夫啸 & 老夫婦 & - & - & 3.8 & 3.0 & 0.8 & 10.4 & - & 0.74 & 0.2 & 130 \\
\hline & 二世帶 & 二世农 & - & - & 9.0 & 6.9 & 2.1 & 24.1 & - & 0.75 & 1.4 & 120 \\
\hline \multirow{3}{*}{ あり } & 核家族 & 住宅 4 (床) & 標準 & 標隻 & 5.0 & 3.9 & 1.0 & 13.7 & 3.7 & 0.97 & 0.4 & 160 \\
\hline & 老夫婦 & 老夫婦 (床) & - & - & 3.6 & 3.0 & 0.6 & 10.4 & 4.5 & 1.15 & 0.4 & 120 \\
\hline & 三世带 & 二世带 (床) & - & - & 8.6 & 6.9 & 1.6 & 24.1 & 8.2 & 1.05 & 0.8 & 220 \\
\hline
\end{tabular}

表 5 発電機運転スケジュール

※表中の熱電比はエネルギー消費段階での算定值であり、エアコン冷暖房を用いる場合はエアコン動力を電力負荷側に合算している。

\begin{tabular}{|c|c|c|c|}
\hline 季節 & \multicolumn{3}{|c|}{ 選択された発電機運転スケジュール（時間帯： $\times$ 時 00 分〜口時 00 分まで) } \\
\hline 凡例名 & 冬期 & 中間期 & 夏期 \\
\hline 住宅 1 & $6 \sim 7, \quad 17 \sim 23$ & $18 \sim 23$ & $18 \sim 22$ \\
\hline 住宅 2 & $6 \sim 7, \quad 17 \sim 23$ & $18 \sim 23$ & $17 \sim 23$ \\
\hline 住宅 3 & $6 \sim 7, \quad 17 \sim 22$ & $18 \sim 22$ & $18 \sim 22$ \\
\hline 住宅 4 & $6 \sim 7, \quad 17 \sim 23$ & $18 \sim 23$ & $18 \sim 22$ \\
\hline 住宅 5 & $6 \sim 8, \quad 17 \sim 23$ & $6 \sim 7, \quad 18 \sim 23$ & $18 \sim 23$ \\
\hline 住宅 6 & $6 \sim 7, \quad 18 \sim 22$ & $18 \sim 22$ & $18 \sim 22$ \\
\hline 住宅 7 & $6 \sim 7, \quad 17 \sim 22$ & $18 \sim 22$ & $17 \sim 22$ \\
\hline 老夫婦 & $6 \sim 22$ & $6 \sim 22$ & $6 \sim 22$ \\
\hline 二世帶 & $6 \sim 7, \quad 17 \sim 22$ & $18 \sim 22$ & $17 \sim 22$ \\
\hline 住宅 4（休） & $6 \sim 11, \quad 12 \sim 14, \quad 16 \sim 23$ & $6 \sim 8, \quad 12 \sim 13, \quad 17 \sim 23$ & $6 \sim 8, \quad 17 \sim 22$ \\
\hline 老夫婦 (床) & $6 \sim 8, \quad 12 \sim 13, \quad 17 \sim 22$ & $6 \sim 8, \quad 12 \sim 13, \quad 18 \sim 22$ & $17 \sim 22$ \\
\hline 二世帯 (休) & $6 \sim 14, \quad 16 \sim 23$ & $6 \sim 8, \quad 17 \sim 23$ & $6 \sim 7, \quad 17 \sim 22$ \\
\hline
\end{tabular}

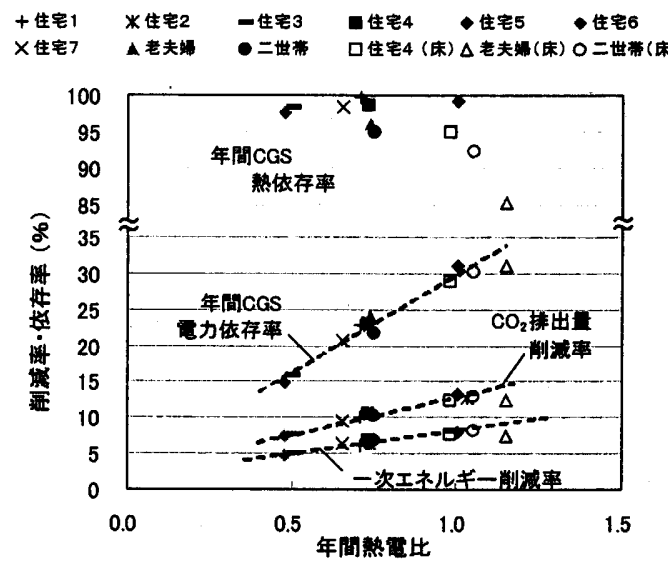

図 12 システム性能と年間熱電比の相関性

\section{6. 種々の住宅負荷に対するシステム性状}

\section{1 検討概要}

住宅負荷の違いが家庭用 CGS のシステム性状に与える影響を考 察するため、4. で示した計 12 の住宅負荷を対象に解析を行った。 導入システムでは、発電機は定格運転されるものとし、発電機容量, 貯湯槽容量および運転スケジュールについては、容量適正化の処理 を行って住宅毎に選定するものとした。

住宅負荷の算出結果と各住宅の年間熱電比（熱負荷／電力負荷）、 さらに解析によって得られた各住宅の発電機容量と賍湯槽容量を表 4 に、選定された各期の発電機運転スケジュールを表 5 に示す。

\section{2 年間熱電比とシステム性能の相関性}

図 12 に住宅負荷の年間熱電比とシステム性能の関係を示す。図よ り、一次エネルギー削減率、 $\mathrm{CO}_{2}$ 排出量削减率および年間 CGS 電力 依存率は、年間熱電比との間に非常に強い線形相関を持つことが分 かる。年間 CGS 熱依存率については、㦿暖房を用いる老夫婦住宅を 除けば各住宅とも $90 \%$ 以上の高い值であるため、システム性能を決 める支配要因は CGS 電力依存率となっていると言えよう。また、核 家族や老夫婦住宅など、日負荷パターンが異なる種々の住宅負荷を 設定したが、結果的として図 12 のように整理できるため、GE 発電 機を用いた場合の導入効果(一次エネルギー削減率, $\mathrm{CO}_{2}$ 排出抑制効 果）は、基本的には住宅の年間熱電比に依存すると考えて良い。

同図より、床暖房を使用する場合には GE システムは一次エネル ギー削減率が若干高くなることが分かる。これは、床暖房を使用す る場合には GE 排熱を床暖房に利用できることで発電機の稼働時間 が長くなり、CGS 電力依存率が約 $6 \%$ ～8\%高くなるためである。

\section{3 機器容量とシステム举動}

図 13 に標準的な核家族(住宅 4), 老夫婦，二世帯の各住宅に対す る1月平日のシステム挙動状況を床暖房の有無別に示す。

図 13 および表 5 より、床暖房を用いない場合には、電気・熱需要 の高い時間帯となる朝と晚を中心に発電機が稼㗢し、給湯需要が増 大する夜間にむけては、夕方の 17 時あたりから短時間で賍湯されて いるのが分かる。一方、床暖房を用いる場合は、朝から夜にかけて 断続的に現れる床暖房需要に合わせて発電機が稼働するため、これ に伴って排熱回収による貯湯も長時間に亘って行われている。

図 13 にて補助バーナの稼働状況を見ると、休暖房を用いない場合 は全く稼㗢しておらず、床暖房を用いる場合には床暖房の立ち上が り時間帯である朝方と、夜に貯湯槽の残湯が無くなったあとに稼働 している。床暖房を用いる場合は、用いない場合よりも小さな発電 容量となるがゆえに排熱出力も小さくなり、加えて CGS 排熱が床暖 房にも利用されるため、貯湯槽に残湯がなくなったあとの入浴では、 補助バーナによる給湯に頼らざるを得ない状況となる。

床暖房を用いる場合は、結果として発電機稼働の長時間化による CGS 電力依存率の向上がシステム性能の向上に謨がっている。発電 機の長時間稼衝のためには、余剩電力の発生を極力抑制する必要が 生じ、床暖房を用いない場合よりも発電容量が小さくなる。また、 発電機の小容量化に伴って排熱出力も小さくなるため、夜間稼働時 の回収排熱による直接給湯熱量も減少する。これを補うために、貯 湯能力を増加させて昼から夜にかけて断続的に回収される CGS 排 熱を夜間に持ち越す必要が生じ、賍湯槽容量が大型化する。 


\section{7. 家庭用 CGS の容量設計法の提案}

\section{1 容量選定係数の定军}

本論で提案する家庭用 CGS の装置容量選定法は、一次エネルギー 消費削減を主眼に置き、以下のように設計パラメータを考えた。

（1）発電機容量

標淮的な核家族住宅（住宅 4)への GE システムの導入に対し、 種々の発電機容量を与えた場合の月別および年間システム性能を図 14 に示す。なお、貯湯槽容量と発電機の運転スケジュールについて は、発電機容量ごとに容量適正化処理を行って選定されている。

図より、各発電機容量に対する一次エネルギー削減率は、その差 が冬期・夏期よりも中間期に比較的顕著に現れるため、中間期の性能 が年間性能を決定つけると考えられる。年間性能は電力依存率の推 移と連動しており、この電力依存率は余剩電力量に依存している。 そこで、発電機容量は中間期の電力負荷を対象に、日䅡算値という よりも発電出力との関連に着目して定めるのが適当と考えて、発電 機容量の選定係数 Rge を(5)式のように定義した。Rge は、「中間期 の最大時間電力負荷」に対する「発電機定格出力」の割合を意味する。

(2) 貯湯槽容量

標準的な核家族住宅(住宅 4)への GE システムの導入に対し、 種々の貯湯槽容量を与えた場合の月別および年間システム性能を図
15 に示す。なお、発電機容量とその運転スケジュールは、設定した 貯湯槽容量ごとに容量適正化処理を行って選定されている。

図より、各槽容量に対する一次エネルギー削减率は、冬期におい て特に大きな差がみられ、これは電力依存率もさることながら、冬 期の CGS 熱依存率の低下にも関係が深いと考えられる。そこで、貯 湯槽容量は冬期の日給湯負荷を対象に定めるのが適当と考え、貯湯 槽容量の選定係数 Rst を(6)式のように定義した。このRst は、「冬期 の最大日給湯負荷」に対する「貯湯槽の蓄熱容量」の割合を意味する。

$$
\begin{aligned}
& R_{g e}=P_{g e} / L_{e, \text { md, hour }} \\
& R_{s t}=C \rho \cdot V_{s t} \cdot\left(T_{s t, \text { win }}-T_{s p, \text { min }}\right) / L_{d, \text { win, day }}
\end{aligned}
$$

\section{2 容量設計法の提案}

(1) 発電容量の選定

図 16 に、発電機容量の選定係数 Rge と一次エネルギー削減率の関 係を床暖房の有無別に示す。図中のプロットは、核家族と老夫婦お よぴ二世帯住宅において種々の発電機容量を与えた場合の結果であ り、それぞれの発電容量に対する賍湯槽容量と発電機の運転スケジ ュールは、容量適正化処理を行って選定されている。

図より、床暖房なしでは Rge が 0.6 前後、床暖房ありでは 0.4 前 後でエネルギー削減率が極大となる。つまり、この值を用いて種々
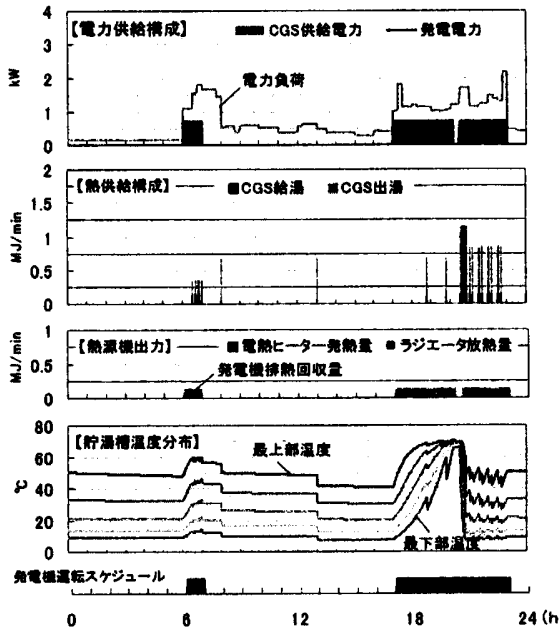

（a）核家族住宅：住宅 4（床暖房なし）
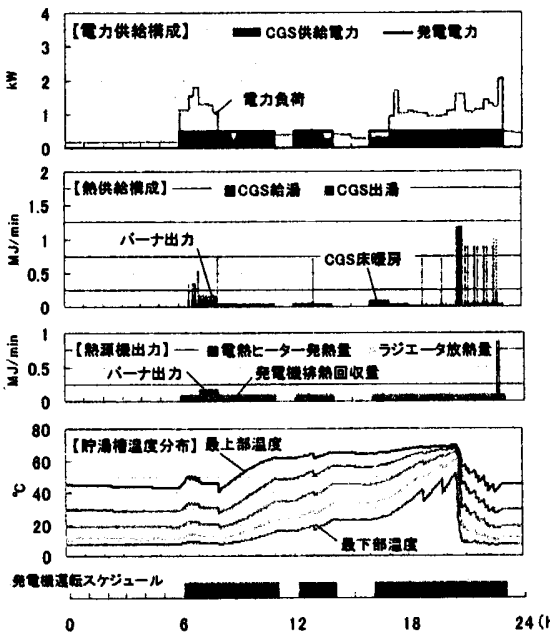

(a) 核家族住宅 : 住宅 4 (床暖房あり)
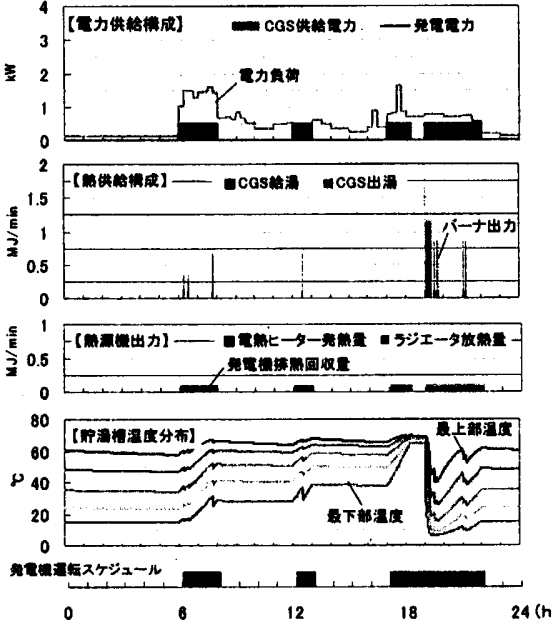

（b）老夫婦住宅（床暖房なし）
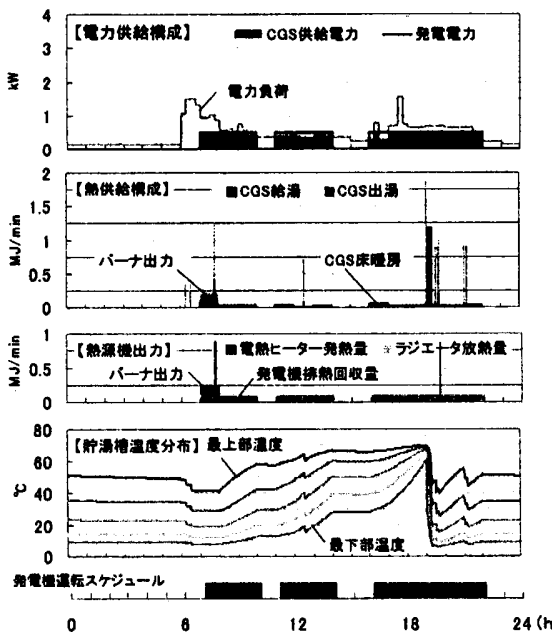

（b）老夫螮住宅（床暖房あり）
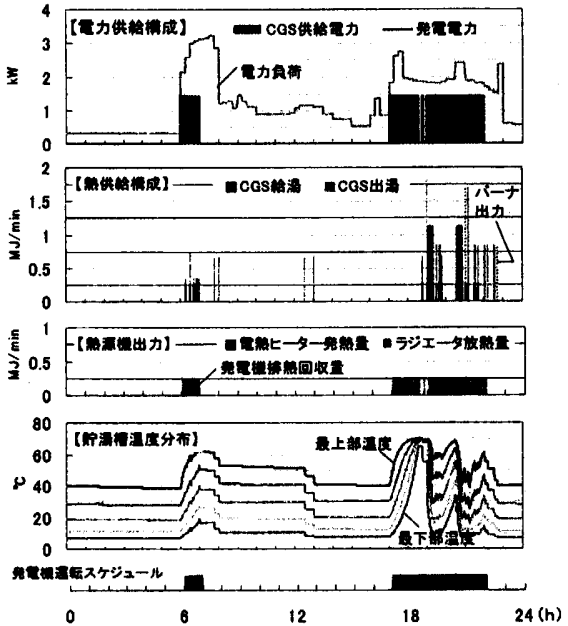

(c) 二世帯住宅（床暖房なし）

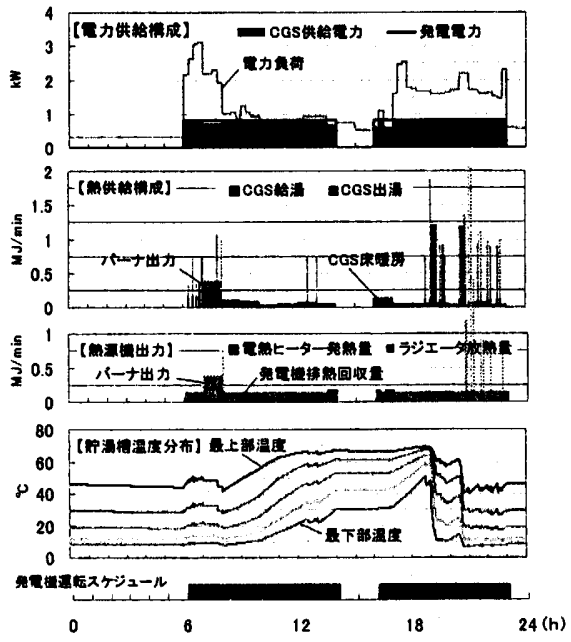

（c）二世帯住宅（休暖房あり）

図 133 種の住宅に対する冬期のシステム挙動（1月の平日） 
の導入住宅に対する発電機容量が適正に導出できる。また、本条件 下では発電機容量が床暖房採用時に 3 割程度小さくなる。これは年 間熱電比が大きくなるとRge 值が小さくなる傾向を持つことを表す。 （2）貯湯槽容量の選定

図 17 には、貯湯槽容量の選定係数 Rst と一次エネルギー削減率の 関係を床暖房の有無別に示した。図中のプロットは、図16で用いた 解析結果を貯湯槽容量基準で再整理したものである。図より、床暖 房なしでは Rst が 0.6 前後 (老夫婦住宅では、0.7 余りと若干大きめ)、 床暖房ありでは 0.8 前後でエネルギ一削减率が頭打ちとなる。よっ て、この值を用いることで貯湯槽容量を種々の導入住宅に対して適 正に選定できると考えられる。また、床暖房採 用時には貯湯槽容量が 3 割程度大きくなってお り、これは年間熱電比が大きくなるとRst の値 も大きくなる傾向があることを表している。

\section{3 機器容量設計法の吟味}

設計法の妥当性の検討行うため、表 4 の各住 宅負荷に対し、発電機 $1 \mathrm{~kW}$ ，貯湯槽 $150 \ell の$ 標 準容量システムを導入した場合と、床暖房あり $R g e=R s t=0.6 、$ 床暖房なし $: R g e=0.4, R s t=0.8$ で設計した場合（以下、容量適正化システムと 呼ぶ)の解析を行った。

図 18 には、各住宅に標準容量システムを導入 する条件で求めた Rge, Rst とその適正値との差 である $\Delta R g e, \Delta R s t$ 注8) と、容量適正化システ ムからの一次エネルギー削減率の低下率の関係 を示す。なお、図中の縦軸負側が削減率低下を 表す。図より、RgeやRst が適正值から離れる ほど一次エネルギー削減率の低下割合も大きく なっている。この結果より、本論の検討範囲で はRgeおよびRstを設計パラメータとして用い

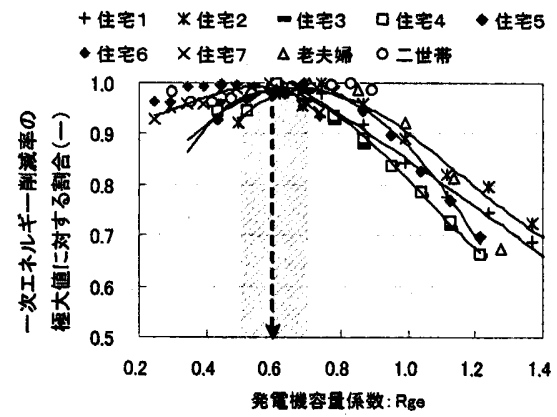

図 16(a) Rge とエネルギー削减率（休暖房なし）

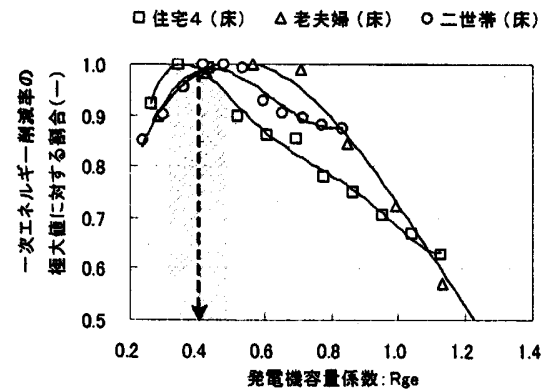

図 16(b) Rge とエネルギ一削減率（休暖房あり）
ること、そして本論で示した Rge，Rst の適正值を用いた設計が、概 算設計としては妥当であったと判断できる。

また、図 18(a)では、 $\Delta R g e$ と一次エネルギー削減率の低下割合に 比例関保が見られる。これは、貯湯槽の標準容量 $(150 \ell)$ と適正貯湯 容量の差が特に大きくなる住宅 1 や住宅 3 、二世帯 (床)のケースを

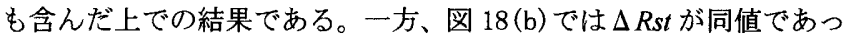
ても一次エネルギー削減率の低下割合には比較的大きな差が見られ るケースが存在する。これらの結果は、システムの一次エネルギー 性能を決める要因としては、貯湯槽容量の適正化よりも発電機容量 を適正に与えることの方が影響が大きいことを指し示している。

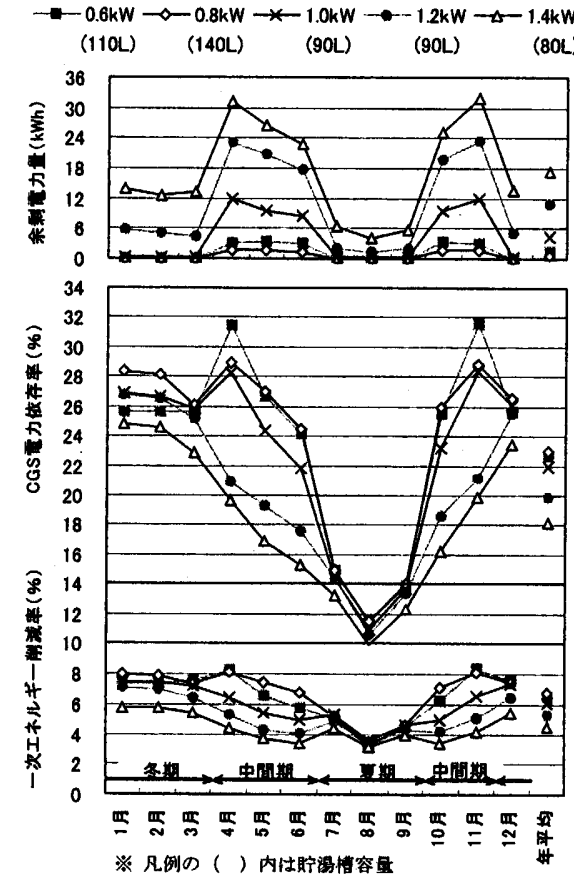

図 14 発電機容量による性能変化(住宅 4)
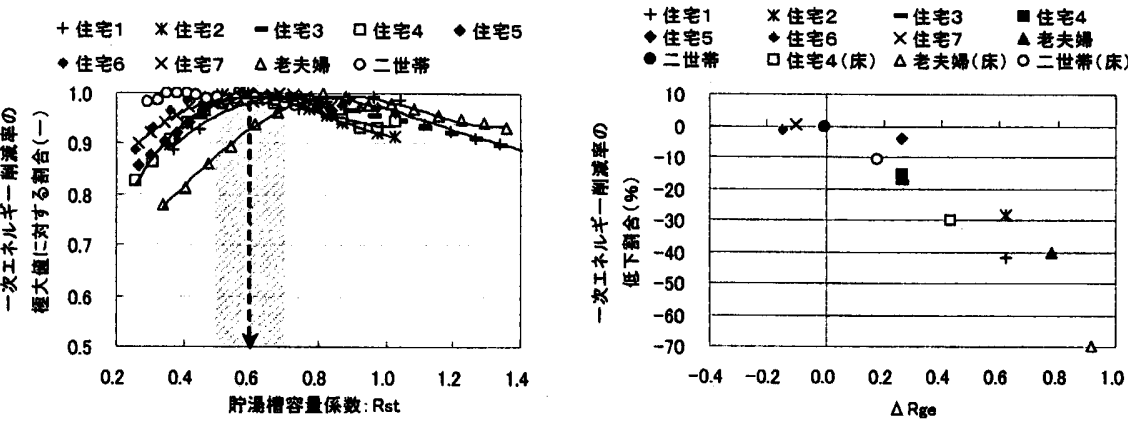

図 17 (a) Rge とエネルギ一削減率(床暖房なし) 図 18(a) $\Delta R g e$ とエネルギー削減率の関俰
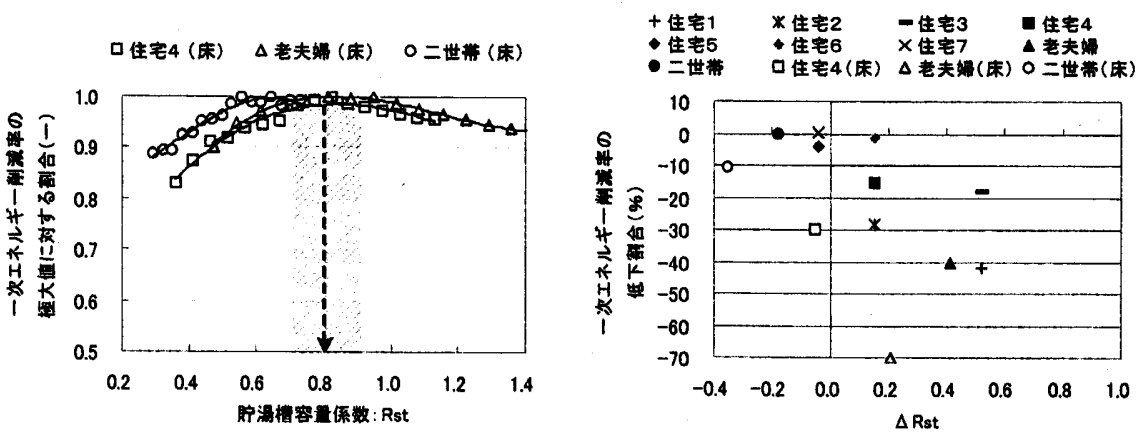


\section{8. まとめ}

家庭用 CGS の解析プログラムを開発し、システムの導入効果予測 手法と容量設計手法 (発電機容量, 貯湯槽容量の選定方法)の提案を 目的に種々の検討を行って、以下の結論を得た。

（1）システム実証試験データとの比較から、解析結果は実システム の挙動状態と良い一致を示し、日積算一次エネルギー消費量の誤 差も約 $3 \%$ と僅かであったため、解析プログラムは妥当と判断した。 （2）発電機の運転方法として定格運転と電力負荷追従運転を設定し、 種々の住宅負荷（核家族や老夫婦、二世帯住宅など）を対象に解析 を行った。年間一次エネルギー削减率には運転方法による大きな 差は見られず、制御が簡易となる定格運転が優位と結論づけた。

（3）種々の住宅負荷に対して貯湯槽容量と発電機容量さらには定格 運転を前提に発電機の運転スケジュールを適正化してシステム性 能を分析した。年間エネルギー性能と年間熱電比の間には、家族 構成に依らず非常に強い線形相関が見られたため、システムの導 入効果は住宅負荷の年間熱電比を以て推定できることを示した。

（4）核家族住宅を対象に、発電機容量を $0.2 \mathrm{~kW} \sim 1.6 \mathrm{~kW}$ で変化させ、 また貯湯槽容量と定格運転を前提に発電機の運転スケジュールの 適正化を行って解析した。条件間では中間期のエネルギー性能に 比較的大きな差がみられ、これは CGS 電力依存率に依存した。そ こで、中間期の電力負荷と発電機出力の関係から発電機容量を定 めることを考え、発電容量の選定係数として「中間期の最大時間電 力負荷」に対する「発電機定格出力」の割合であるRge を提案した。 （5）核家族住宅を対象に、貯湯槽容量を 50 亿 450 とで変化させ、ま た発電機容量と定格運転を前提にその運転スケジュールの適正化 を行って解析した。条件閒では、冬期のエネルギー性能に比較的 大きな差がみられ、これには特に CGS 熱依存率の変化が大きな影 響を与えていた。そこで、貯湯槽容量を冬期の日給湯負荷を対象 に定めることを考え、槽容量の選定係数として「冬期の最大日給湯 負荷」に対する「貯湯槽の蓄熱容量」の割合であるRst 提案した。

（6）種々の住宅負荷を対象に、様々な発電機容量と貯湯槽容量を仮 定して解析を行い、Rge およびRs と一次エネルギー削減率の関係 性を検討した。床暖房ありでは $R g e=R s t=0.6$ 、床暖房なしでは Rge $=0.4, R s t=0.8$ あたりでエネルギー性能が極大または頭打ち となることを示し、この值を概略設計に用いることを提案した。

（7）種々の住宅負荷に標準システム容量(発電機 $1 \mathrm{~kW}$, 貯湯槽 $150 \ell$ ) を与えて解析を行い、この場合の Rge とRst を算定して容量適正 化システム（(6)で示した適正值を用いて設計したもの）とエネル ギ一性能を比較した。その結果、Rge，Rst が提案した適正值から 離れるほどシステムの年閒一次エネルギー削减率は低下するとい う傾向が確認できたため、この設計法は妥当であると判断した。

【謝辞】

本論文の作成にあたっては、東邦ガス株式会社に贵重な御意見を頂いた。また本研究 の一部は、平成 $15 \sim 17$ 年度科学研究費補助金(若手研究(B), 課題番号 15760438 , 代表 者：田中英紀)の補助を受けて実施された。末尾ながら、ここに記して謝意を表す。

一記号一

$R_{w h}$ : 排熱利用率 $(-), \sigma_{e}:$ CGS 電力依存率 $(-), \sigma_{h}:$ CGS 熱依存率( $(-), C G S_{e f f}$

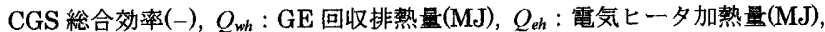
$Q_{n d}$ : ラジエータ処理熱量 $(\mathrm{MJ}), Q_{l o s s}$ : 貯湯槽損失熱量 $(\mathrm{MJ}), Q_{b u}$ ：ガスバーナ 加熱量 $(\mathrm{MJ}), Q_{l d-d}$ : 給湯熱負荷 $(\mathrm{MJ}), Q_{l d-f}$ : 床暖房負荷 $(\mathrm{MJ}), E_{l d}$ : 電力負荷 $(\mathrm{kWh}), E_{u t}$ : 貫電量 $(\mathrm{kWh}), E_{\mathrm{ge}}: \mathrm{GE}$ 発電量 $(\mathrm{kWh}), E_{p e x}$ : 排熱回収用ポンプ $(2$ 台分)電力消費量 $(\mathrm{kWh}), E_{\text {eh }}$ : 電気ヒー夕送電量 $(\mathrm{kWh}), G_{g e}$ : GE ガス消費量 $\left(\mathrm{m}^{3}\right), P_{g e}: \mathrm{GE}$ 定格出力 $(\mathrm{kWh}), R_{g e}$ : 発電容量選定係数 $(-), R_{\mathrm{st}}:$ 貯湯槽容量 選定倸数 $(-), L_{e}$ : 最大電力負荷 $(\mathrm{kWh}), L_{d}$ : 最大給湯負荷 $(\mathrm{MJJ}), C \rho:$ 水の容 積比熱 $\left(\mathrm{kJ} / \mathrm{m}^{3}\right), V_{s t}$ : 貯湯槽容積 $\left(\mathrm{m}^{3}\right), T_{s t}$ : 貯湯温度 $(\mathrm{K}), T_{s p}$ : 給水温度 $(\mathrm{K})$ 添字一hour : 時間積算, day : 日積算, win : 冬期, $m d$ : 中間期, $m i n$ : 最低

注 1）(財) 新エネルギ一財団：経済産業省の固体高分子形燃料電池システム塞 証等研究費補助金による「定置用燃料電池実証研究」, 2002 2004など

注 2）定格出力または最低部分負荷設定を維持して発電を行う場合、発電電力 が電力負荷を上回る時間帯には余剩発電電力が生じる。この余剩電力は、 エネルギーやエクセルギー損失低減の観点からは逆潮流を行うのが望ま しいが、契約上の制限あるいは逆潮流契約が可能になったとしても経済 性の観点からは成立し得ない状況にあるため、本論では余剩発電電力を 熱変換して処理するのが現実的と考えて、これを仮定した。

注 3）総当たり計算では、発電容量は $0.2 \mathrm{~kW} \sim 1.6 \mathrm{~kW}$ の範囲を $0.1 \mathrm{~kW}$ 刻みで、 眝湯槽容量は 50 ん 450 のの範囲を 10 刻みで条件を与えている。運転 スケジュールは、24 時間連続運転と 40 通り以上の閒欠運転スケジュー ル（夕〜晚型，朝・夕〜晚型，朝・昼·夕〜晚型を想定し、朝および昼は食 事の時間带を中心に、夕〜晚は 15 時から就寝後数時間迄の時間内で組 み合わせを設定）の中から、冬期，夏期，中間期の季節別に選択される。

注 4） $1 \mathrm{~kW}$ のガスエンジン発電機の試験データを参考に仮定した特性曲線。

注 5) 一次エネルギー換算値は、商用電力： $9.83 \mathrm{MJ} / \mathrm{kWh}$ (全火力平均)、都市 ガス：46.05MJ/Nm ${ }^{3}$ を用いた。二酸化炭素排出量は、電力： $0.657 \mathrm{~kg} \cdot \mathrm{CO}_{2}$ (全火力平均)、都市ガス: $2.15 \mathrm{~kg} \cdot \mathrm{CO}_{2}$ を用いた。

注 6）東邦ガス侏の環境試験室にて行われた試験デー夕をもとにしている。実 測生データは秒単位であるが、分単位に整理して利用している。なお、 追焚き負荷は專用ガスバーナで処理され、排熱利用系統には接䋨されて いない。電力量は電力計を、ガス消費量はガス流量計を用いて計測し、 各種熱量は温度差と循環流量から算定している。循環ポンプ動力は計測 されておらず、実測データは入手できなかった。

注 7）最低部分負荷率として $20 \%$ 70\%の範囲を $10 \%$ 刻みで与えて予備検討 を行った結果、50\%の条件でエネルギー性能が最も高くなった。

注 8）解析プログラムでは、発電機の運転スケジュールを予め設定した多くの 組み合わせから最もエネルギー性能が高くなるものを選択するため、運 転スケジュールは適正化されているとする。また、市販機器についても、 人工知能(AI)等の学習機能により、発電機運転スケジュールの適正化を 図っており、実機においても本節の仮定は成り立つと考えている。

注 9）発電機 $1 \mathrm{~kW}$ ，貯湯槽 150 しの基準システム条件におけるRge とRstの值 から容量適正化システムの Rge とRstの值をそれぞれ差し引いたもの。

【参考文献】

1）滝本桂阙：家庭用コージェネレーションシステムフィールドテスト結果, コージェネレーション, Vol.16, No.1, pp.39-43, 2001

2) Inaka H., et al.: The development of effective heat and power use technology for residential in a PEFC co-generation system, Journal of Power Sources, 106, pp.60-67, 2002

3）鶼飼邦弘ほか 3 名: 家庭用 PEFC コージェネレーション/水素生成器開発, エネルギー・資源，Vol.23，No.1，pp.68-71，2002

4）(財) 産業創造研究所, 家庭設置型小規模分散型エネルギーシステムに関す る調查報告書, pp.37-59, 1998.3

5）日本建築学会・日本環境管理学会編：建築の次世代エネルギー源，井上書 院, pp.26-28, 2002.12

6) 田村英雄監修 : 固体高分子形然料電池のすべて，電子とイオンの機能化学 シリーズ Vo.4, NTS, pp.301-325, 2003.10

7) ASHRAE : HVAC2 TOOLKIT - A Toolkit for Secondary HVAC System Energy Calculations, pp.4.8-4.8, 1993

8）中原信生ほか 4 名：建筑学大系 27 (設備計画)，彰国社，p.285，1982

9）(社) 空気調和·衛生工学会, SHASE·M0001·1·1994, 都市ガスによるコー ジェネレーションシステム計画・設計と評価，pp.169-170，1994.6

10)（社）空気調和・衛生工学会 : 空気調和・衛生工学会シンポジウム「住宅にお ける生活スケジュールとエネルギー消費」テキスト，2000.3

11)（社）空気調和・衛生工学会 : 空気調和·衛生工学会シンポジウム「住宅にお ける生活スケジュールとエネルギー消費」，配布プログラムISCHEDULE Ver.2.0」, 2000.3

12）(財)建築環境·省エネルギー機構：住宅用熱負荷計算プログラム SMASH for Windows, Ver.2, 2000

13）太陽エネルギー利用ハンドブック編集委員会:太陽エネルギー利用ハンド ブック，太陽エネルギー学会, p.621

14）德島直子ほか 8 名 : 住宅の浴槽からの排水熱利用に関する実態調査 その 1 その 2 , 空気調和・衛生工学会論文集 II, pp.1045-1052, 1999 